\title{
Impact of Mechanical and Biological Watershed Treatments on Surface Runoff
}

\author{
Mehrdad Safaei ${ }^{1}$, Akram Mahan $^{2 *}$ \\ ${ }^{1}$ Agricultural and Natural Resources Research Center of Mazandaran, Mazandaran, Iran \\ ${ }^{2}$ Isfahan (Khorasgan) Branch, Islamic Azad University, Isfahan, Iran \\ Email: ^akram_mahan@hotmail.com
}

How to cite this paper: Safaei, M. and Mahan, A. (2018) Impact of Mechanical and Biological Watershed Treatments on Surface Runoff. Open Journal of Geology, 8, 896-912.

https://doi.org/10.4236/ojg.2018.89053

Received: July 16, 2018

Accepted: August 24, 2018

Published: August 27, 2018

Copyright (c) 2018 by authors and Scientific Research Publishing Inc. This work is licensed under the Creative Commons Attribution International License (CC BY 4.0).

http://creativecommons.org/licenses/by/4.0/

(c) (i) Open Access

\begin{abstract}
Floods are common types of water-related natural hazards that cause not only destruction and loss of lives but also erosion and sedimentation. Soil and water conservation (SWC) techniques such as mechanical treatments (placing check dams) and biological treatments (vegetation restoration) are being applied to reduce the velocity of runoff and mitigate the impact of floods. In this research, we evaluated four different SWC scenarios to see how the watershed responds to those watershed treatments. We calibrated and validated a rainfall-runoff model to simulate the impact of biological and mechanical treatments on peak discharge and volume of the runoff in Bishebone watershed in the north of Iran. Simulation of peak discharge for before and after watershed treatments for floods with return periods of 2 to 100 years shows that, the combination impact of mechanical and biological treatments on floods with return period of 100 years is 6.95 to 9.94 percent. Results also show that the impact of mechanical treatments on floods with higher return periods is relatively more than that of shorter return periods.
\end{abstract}

\section{Keywords}

Flood, Hydrologic Modeling, Watershed Treatment

\section{Introduction}

Floods are common types of water-related disasters, occurring in both developing and developed countries. Floods are accountable for more than one third of disaster-related losses and two thirds of the total disaster affected population of the world (ISDR, 2005) ${ }^{1}$. Recent local studies showed that frequency and intensity of floods has been significantly increased in different parts of Iran during

${ }^{1}$ International Strategy for Disaster Reduction. 
last few decades. The number of floods increased from 215 in the 1960s to 405, 812, and 2053 over the subsequent three decades [1]. It has been more than four decades that Soil and Water Conservation (SWC) techniques have been practiced in many watersheds in Iran [2]. It has also been reported that the optimum results for watershed management using mechanical and biological structures will be achieved by considering two important factors, appropriate constructions with respect to natural characteristics of the watersheds, and impact of the structures on vegetation as a natural barrier for runoff and sediment transports [3] [4] [5] [6].

Due to a variety of ecological characteristics it is difficult to offer a unique solution to address environmental problems for all watersheds. Therefore, in addition to identifying the hydrological characteristics of watersheds, it is important to prioritize the types of SWC techniques for watershed treatment.

One of the most common SWC techniques used in different hydro-climatic region of the world is placing check dams. A check dam is a structure made of concrete, stone or other materials, constructed across the flow channel to be used as a barrier for water and soil loss by reducing water flow velocity [7].

Numerous case studies have been carried out to investigate the impact of check dams and vegetation cover on decreasing runoff and sediments [8] [9] [10] [11].

Some other methods have also been suggested to control the surface runoff in watersheds and prevent the devastating effects of floods. [3] suggested the multi-reservoir cascade systems to minimize the peak discharge of watershed discharge. [12] evaluated the combination of structural and non-structural methods for controlling the flood events.

Using an appropriate hydrologic model we are able to simulate the hydrologic response of watersheds to all of the abovementioned techniques and evaluate the results.

The aim of this study is to evaluate the impact of check dams and vegetation as mechanical and biological SWC techniques using HEC-HMS model. We evaluated 4 different scenarios in which the watershed is being treated by SWC techniques.

The U.S. Army Corps of Engineers Hydrologic Modeling System (HEC-HMS) is a software package for rainfall-runoff simulation. The program is the new version of previous package (HEC-1) in which the performance of model is significantly improved [13]. The package has been successfully tested in different geographic areas [14] [15]. In the north of Iran, Sahour et al. (2016) applied the HEC-HMS model for rainfall-runoff simulation and they observed a good correlation between simulated and observed peak discharge [16]. In another study in north of Iran, Saghafian et al. (2008) used the HEC-HMS model to quantify the impact of land use alteration on floods intensification [17].

\section{Overview of the Study Area}

The study area is Bishebone watershed located in the north of Iran extending 
from $53^{\circ} 47^{\prime} \mathrm{E}-55^{\circ} 45^{\prime} \mathrm{E}$ to $36^{\circ} 29^{\prime} \mathrm{N}-36^{\circ} 35^{\prime} \mathrm{N}$. The north of Iran has experienced several flood events during past years. The studies showed that the return period of flood in the north of Iran has decreased [18]. Some studies also reported the increase in surface runoff of the area due to land use alteration [17] [19] [20].

The mean temperature varies from $12.5^{\circ} \mathrm{C}$ to $20^{\circ} \mathrm{C}$, and annual rainfall ranges is varying from 718 to $1274 \mathrm{~mm}$ [21]. The highest precipitation in the study area occurs in fall [22].

Bishebone watershed can be divided in 10 sub-basin. The biggest sub-basin, $\mathrm{X}$, with 1274.4 hectares covers almost $16 \%$ of the entire watershed and the smallest one, III, with 218.7 hectares covers almost $2.7 \%$ of area. Table 1 shows the areas of all sub-basin. The elevation of the watershed is varied from 1000 to 2220 meters. Figure 1 shows the topography, Digital Elevation Model and 3-dimensional model of the watershed.

\section{Determining the Decline of Peak Discharge Using HEC-HMS Model}

To determine the impact of biological and mechanical activities on runoff of the study area, first the vegetation map of area was produced from satellite data. Then, HEC-HMS rainfall-runoff model was used for different flood events to calibrate and validate the parameters for each sub-basin. Then, characteristics of each rainfall was determined by analyzing the frequently of event based on time-intensity values. The rainfall intensity data for 15, 30, 45, 60 minutes and 1, $2,3,4,5,6,12,18$ and 24 hours continuities in a 20 years period were analyzed in SMADA software and the values for rainfall intensities in 2 to 100 years return periods were obtained. Using the curve fitting of the data, the envelope fitting were computed and the best distribution were selected. Finally, the curves for 2, 5, 10, 25,50 , and 100 years return periods were introduced to the rainfall-runoff model. Thus, the amount of floods for different return period were simulated.

Table 1. Area and percentage of Bishebone's sub-basins.

\begin{tabular}{ccc}
\hline Sub-basin & Area (hectare) & Percentage of sub-basin to total area \\
\hline I & 1255.71 & 15.77 \\
II & 453.15 & 5.69 \\
III & 218.78 & 2.75 \\
IV & 331.33 & 4.16 \\
V & 699.31 & 8.78 \\
VI & 882.47 & 11.08 \\
VII & 707.91 & 8.89 \\
IIX & 1278.78 & 16.06 \\
IX & 862.31 & 10.83 \\
X & 1274.48 & 16.00 \\
Hole area & 7964.23 & 100.00
\end{tabular}




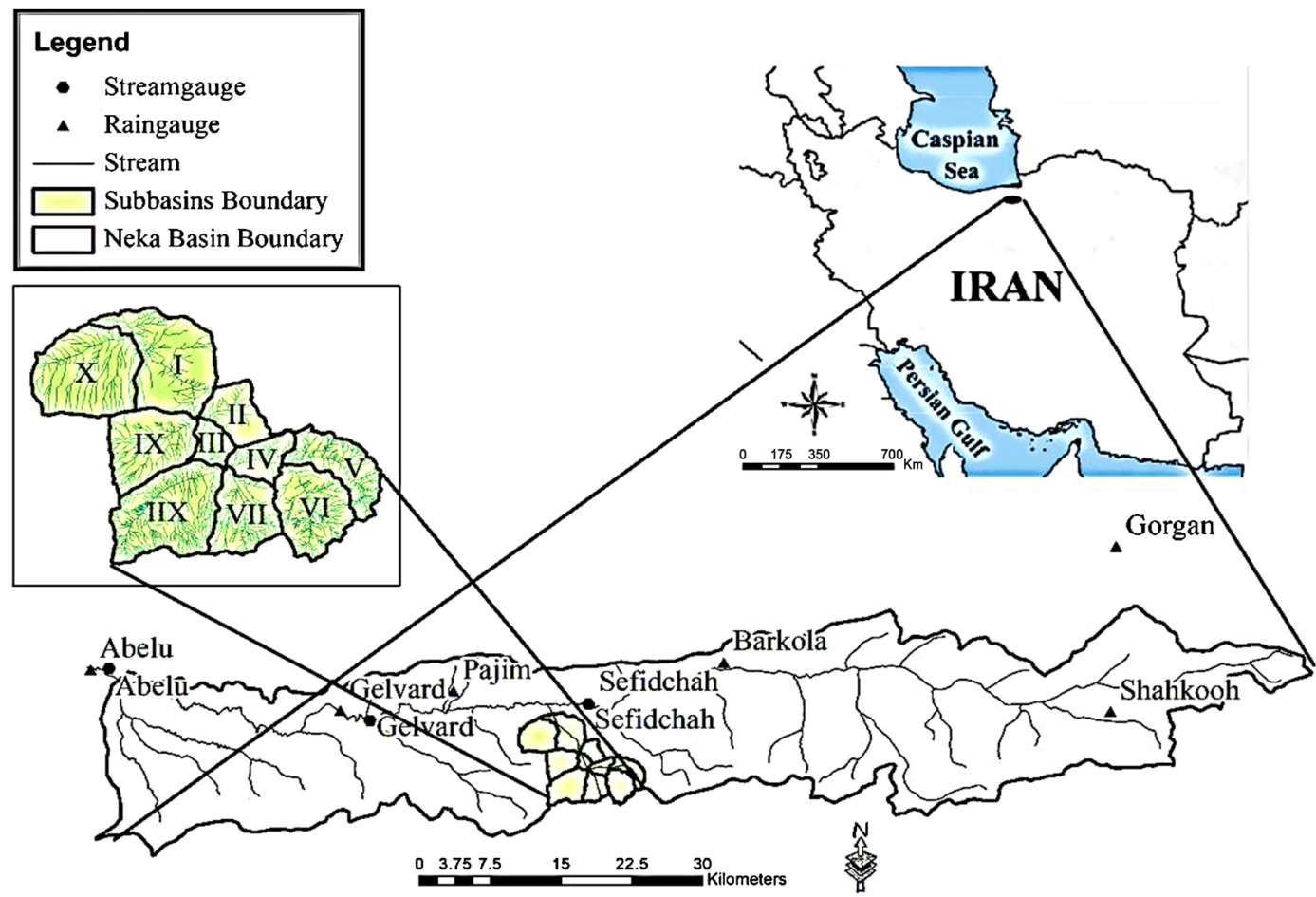

Figure 1. The study of area, Bishebone watershed in the north of Iran.

\section{HEC-HMS Model}

The HEC-HMS model is designed to simulate the precipitation-runoff simulation of watershed systems. HEC-HMS provides a variety of options for simulating precipitation-runoff processes. Digital Elevation Model (DEM) data of the Bishebone basin was a requirement to apply HEC-GeoHMS (USACE-HEC-GeoHMS, 2006) model to develop the basin model. In the process of model development, at first the basin model has to be developed by HEC-GeoHMS using DEM (Figure 2). After that the rainfall-runoff simulation was performed by using the HEC-HMS hydrologic modeling software that includes many popular and well-applicable hydrologic methods. These basin models were imported to the HEC-HMS where there are several options available to run rainfall-runoff accounting for loss, transformation, and base flow calculation for a watershed. For calculation of water loss, the curve number method and SCS-UH model was performed for direct runoff calculation. The base flow then was removed from the total flow and the lag method was used for flow routing.

The meteorological data were analyzed with meteorology component and these components consisted of rainfall data, snow melt and evapotranspiration. Evapotranspiration is used to describe the movement of water from the Earth's surface to the atmosphere by the combined processes of evaporation and transpiration [23]. Because the selected data such as rainfall and runoff data are taken in small time intervals, therefore evapotranspiration is not significant in rainfall-runoff modeling of the study area.

In this study, SCS curve number method used for loss flow calculation and 


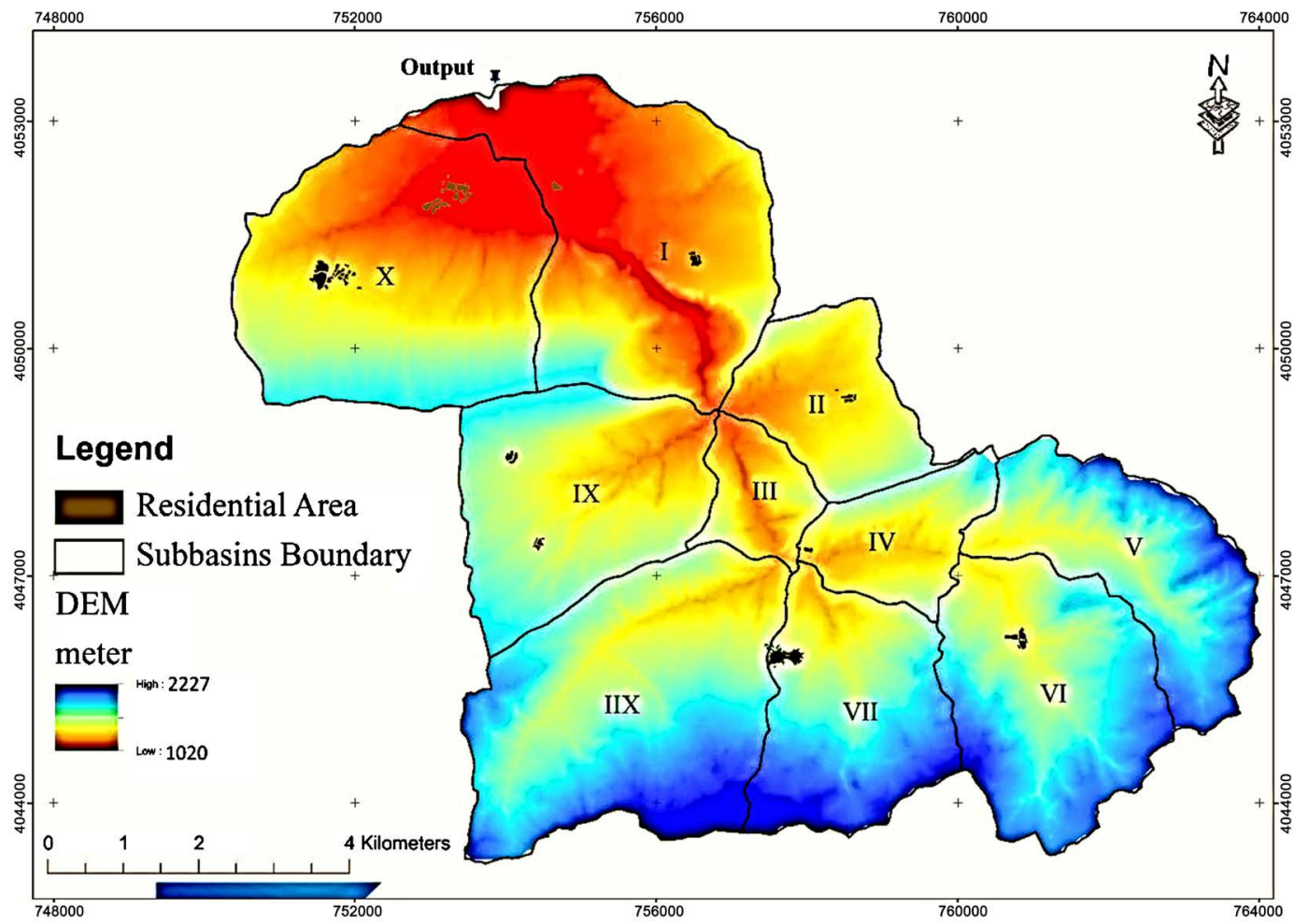

Figure 2. DEM of Bishebone watershed.

SCS unit hydrograph used for direct runoff calculation. The SCS CN is widely used for calculation of runoff in different case studies [24] [25] [26].

The initial abstraction ratio (Ia/S); (initial abstraction Ia-potential maximum retention S) plays an important role in the calculation of runoff depth, the hydrograph peak and the time distribution of runoff. The SCS Curve Number (CN) equation is as following:

$$
\begin{gathered}
\mathrm{S}=(25,400 / \mathrm{CN})-254 \\
\mathrm{Ia}=0.2 \mathrm{~S}
\end{gathered}
$$

In Equation (1), $\mathrm{CN}$ is a dimensionless parameter and is: $0 \leq \mathrm{CN} \leq 100$. When $\mathrm{CN}$ is 100 , soil is not able to absorb rainfall and as a result the height of rainfall and runoff is equal. Ia, is initial abstraction $(\mathrm{mm})$ and $S$ is potential maximum retention $(\mathrm{mm})$. The percent of impervious layer of basin was produced from vegetation cover.

\section{Calibration and Validation of the Model}

We used historical flood events and their corresponding rainfall for calibration and validation. To do this, we observed 5 flood events in time series data from Gelvard hydrometric station and their corresponding rainfalls were identified. Three of the events were used for calibration and two of them for validation. For runoff simulation, parameters were calculated and then, for determining the optimum amount the parameters optimizing method performed for three flood events. To calibrate the model, the simulated hydrographs manually adjusted 
until the best match between observed and simulated hydrographs were observed. The optimize values from calibration step were applied to run the model for two events in validation step.

\section{Sensitivity Analyze}

Sensitivity analysis was used to evaluate the hydrological parameters. The simulated hydrographs were compared the observed hydrographs obtained from Gelvard hydrometric station. To determine the sensitivity to adjusting of the model parameters following equation was used [27] [28].

$$
\mathrm{SEN}=100 \frac{\mathrm{New}-\mathrm{Old}}{\mathrm{Old}|\mathrm{PC}|}
$$

SEN is sensitivity of the target function to changing the value of parameters, New is the new output of new parameter, Old is initial output of model and PC is absolute values for percentage of change in parameters values.

\section{Evaluation of Results}

Pearson correlation confidence (r), root-mean-square error (RMSE) and student's t-test in SPSS software were used in order to evaluate the results. The best simulations belong to rainfall that shows maximum efficiency and minimum P-Value or minimum RMSE [29] [30].

\subsection{Determining the Time of Concentration and Lag Time for before and after SWC Constructions}

Lag time is the time interval between the center of mass of the excess rainfall and the peak runoff rate. In this part of the study we estimated the lag time and the time of concentration for Bishebone watershed before and after implementing SWC structures:

\subsubsection{Before Implementing SWC Structures}

In this study time of concentration $\left(T_{c}\right)$ was estimated using the Kirpich equation for small sub basins [31] [32]. Lag time was calculated using following equation.

$$
T_{\text {lag }}=0.6 T_{c}
$$

\subsubsection{After Implementing SWC Structures}

To evaluate the impact of structures on flow channels slopes, the location of the structure was determined by considering their heights of them and the slope of structure was calculated in the construction site. For this purpose the length of sedimentation was measured and then the new slope was weighted in construction site.

$$
S^{\prime}=\frac{\left(P^{\prime} \times L^{\prime}\right)+(p \times l)}{L}
$$

where $S^{\prime}$ is the new slope in main stem, $P^{\prime}$ is extent, $l$ is the length of flow 
channel that is not influenced by the structure $(\mathrm{m})$ and $L$ is the length of main channel before the operations. By putting the new slope in equation the new time of concentration for the flow channel was determined.

\subsection{Evaluation of Mechanical Treatments (Check Dams) on Peak Discharge Variations}

In this step, the schematic plan for hydrological component of the Bishebone check dams was provided. Then, the basin model for before and after placing check dams were created using the optimized parameters from validation steps and rainfall data to evaluate the impact of check dams on pick discharge variations.

\subsection{Evaluation of Biological Treatments (Vegetation Cover) on Peak Discharge Variations}

The change in vegetation cover was quantified using satellite data (Table 2). We used two land use maps from before and after biological treatments to generate the curve number $(\mathrm{CN})$ of the watershed for each time. To do this, the Hydrologic Soil Groups (HSG) data and land use data were combined in GIS and by using the curve number weighting table, the $\mathrm{CN}$ for the watershed were estimated. The new $\mathrm{CN}$ values for each sub-basin were entered to the model and changes in discharge were evaluated. Figure 3 and Figure 4 show the different types of land cover before and after biological treatments.

\section{Simulation of Flow Using HEC-HMS in Order to Evaluate the Combination of Mechanical and Biological Treatments}

In this step, weighted mean of curve numbers from both mechanical and biological operations were entered to the model to evaluate their impact on peak discharge for different return periods.

\section{Flow Simulation by Using HEC-HMS Model to Mechanical}

In this step, based on the optimized parameters from the first step, the change in peak discharge was estimated in case of complete performing of mechanical operations and land use condition.

Table 2. Land use/land cover of the study area before and after watershed treatments.

\begin{tabular}{ccc}
\hline $\begin{array}{c}\text { Area(hectare) of land use after } \\
\text { watershed treatments-2014 }\end{array}$ & $\begin{array}{c}\text { Area (hectare) of land use before } \\
\text { watershed treatments }\end{array}$ & Land use \\
\hline 5080.26 & 4862.53 & Farm land \\
2617.24 & 2743.66 & Forest land \\
557.22 & - & Rangeland \\
122.69 & 214.93 & Bare land \\
88.30 & 39.57 & Residential areas \\
7964.22 & 7964.22 & SUM \\
\hline
\end{tabular}




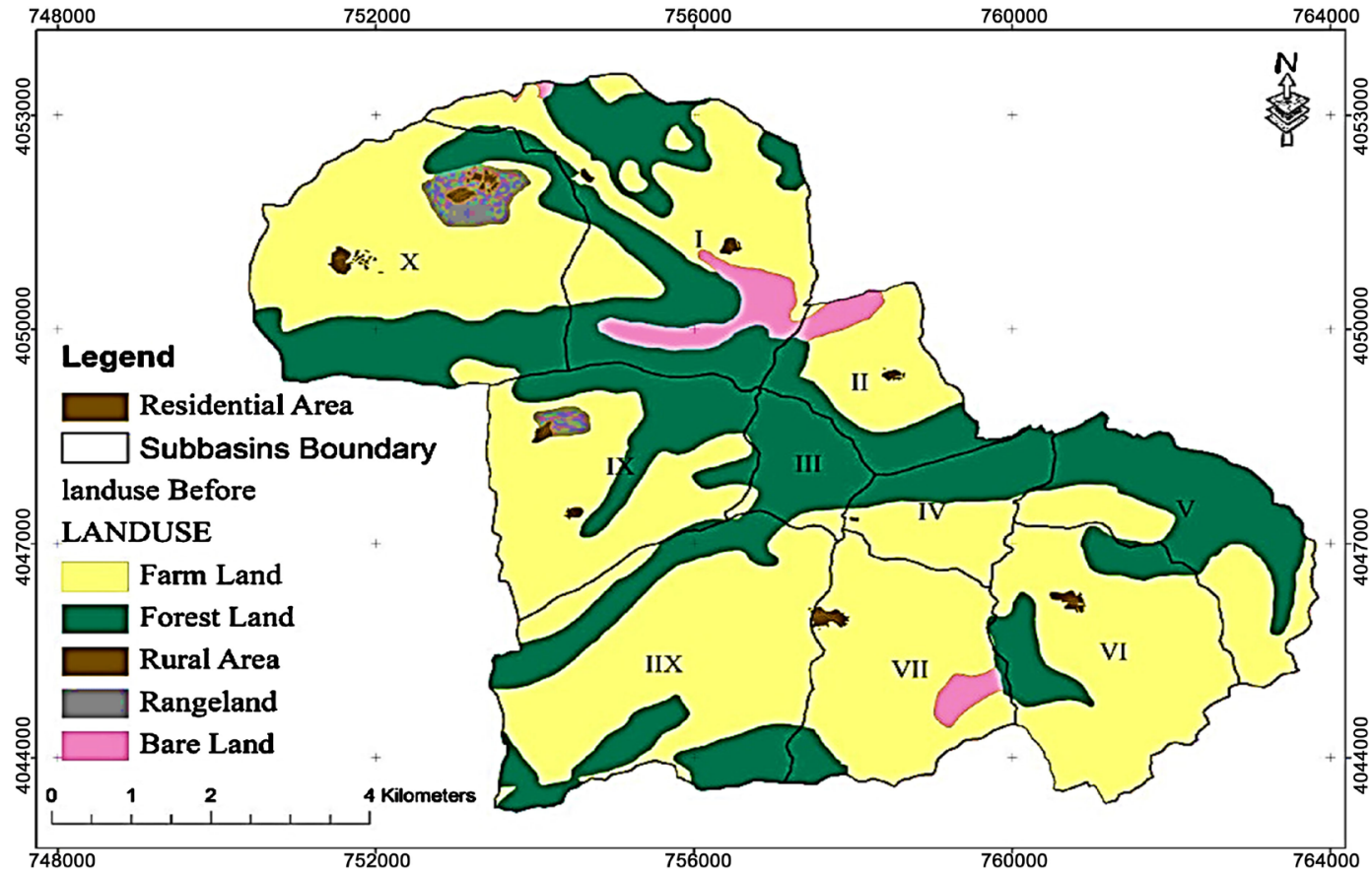

Figure 3. Land cover map of the study area before the watershed treatments.

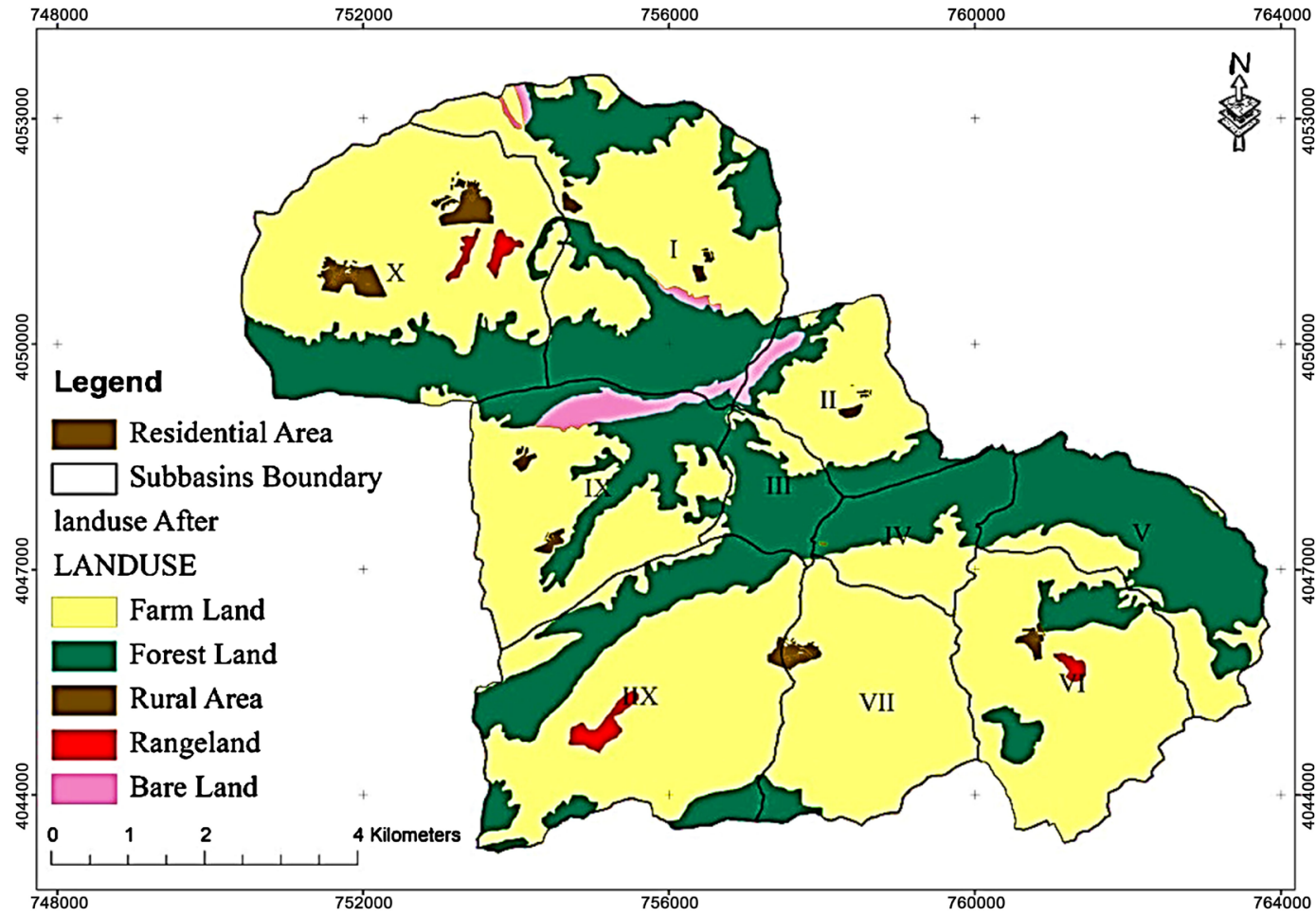

Figure 4. Land cover map of the study area after the watershed treatments.

\section{Results}

\subsection{Characteristics of Mechanical and Biological Structures of the Study Area}

In this step, we describe the characteristics of mechanical structures and biolog- 
ical treatments will be discussed in detail. There are 68 check dams over the flow channels in the study area which two of them have been demolished. Almost 70 percent of the check dams in this watershed are made of stone and mortar and the rest of them are stone field gabions. 33 of the check dams are located in the sub-basin $\mathrm{X}$ which is the highest number of check dams among the sub-basins of the Bishebone watershed. The sub-basin VI with 24 check dams is in the second place. Structural damages mostly happened on the check dams floors. Detailed information about location and characteristics of the structures, land use maps and biological treatments were stored in GIS and were applied to the model. Figure 5 shows the current location of the check dams in Bishebone watershed.

\subsection{CN Calculation}

Table 2 shows the vegetated land surface in Bishebone watersheds. Table 3 shows the amount of $\mathrm{CN}$ in the sub-basin of Bishebone before and after watershed treatments. In general, forest land cover of the study area has been reduced. In the sub-basins V and VI, where the watershed treatments structure were implemented, the $\mathrm{CN}$ values have changed.

\subsection{Rainfall Intensity Evaluation (Intensity-Duration-Frequency)}

In this study, short duration rainfall were estimated using Bell's method (1969). Table 4 and Diagram 1 show the intensity of short duration rainfall Using Bell's method in nearest station called Sefidchah. The reason for applying Bell's

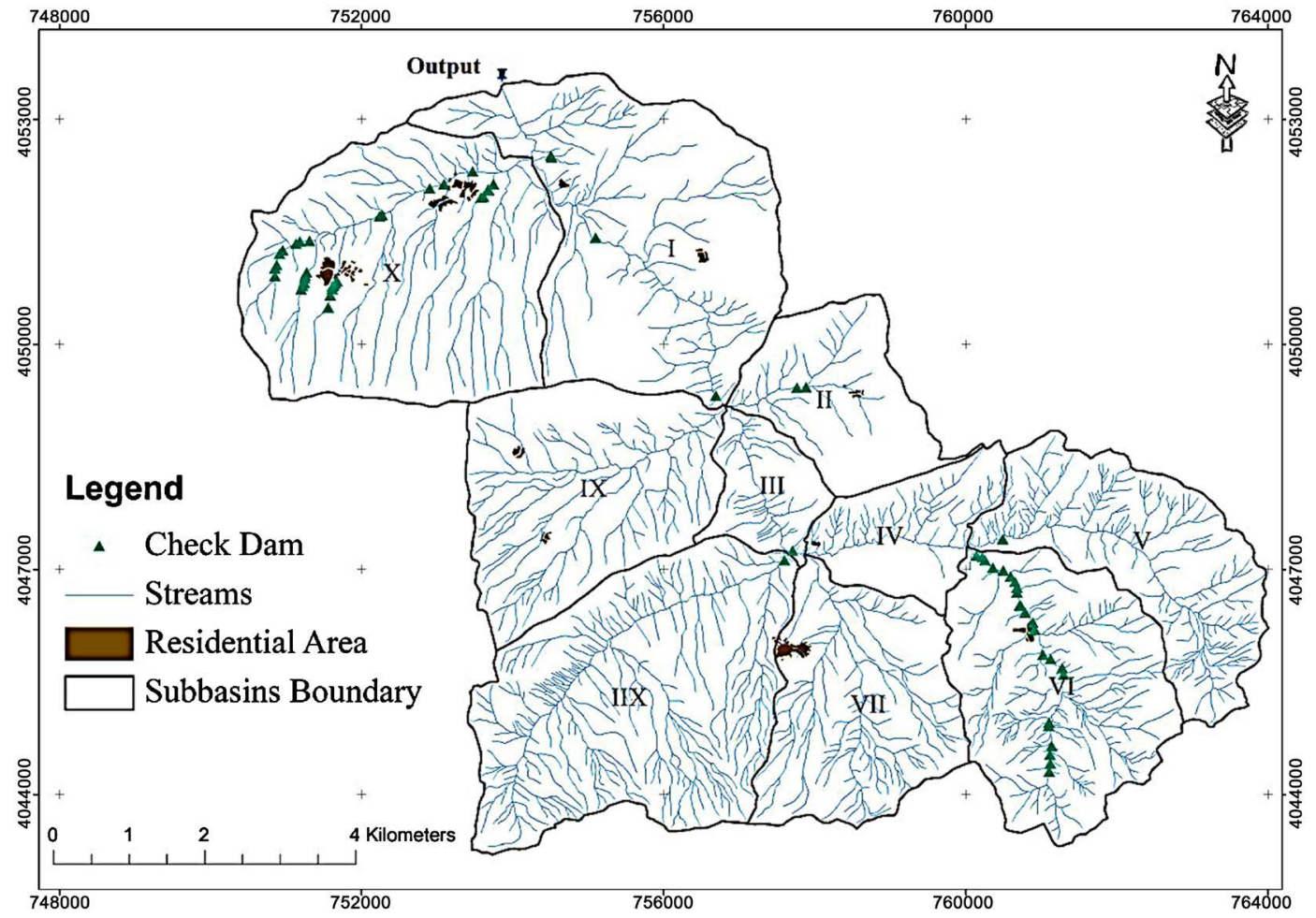

Figure 5. Location of dam in sub-basins of Bishebone Basin. 
Table 3. Values of CN before and after watershed treatments for each sub-basin.

\begin{tabular}{ccc}
\hline Hydrologic Units & Before performing & After performing \\
\hline I & 77.36 & 77.96 \\
II & 78.63 & 79.98 \\
III & 71.94 & 73.05 \\
IIX & 79.53 & 79.68 \\
IV & 77.06 & 75.58 \\
IX & 79.59 & 79.64 \\
V & 75.79 & 73.91 \\
VI & 81.76 & 82.29 \\
VII & 82.82 & 83.42 \\
X & 79.87 & 80.46 \\
\hline
\end{tabular}

Table 4. Intensity-duration-frequency of maximum Rainfall in Sefid Chah-Bell method $(\mathrm{mm} / \mathrm{h})$.

\begin{tabular}{cccccc}
\hline \multicolumn{5}{c}{ Time (Hour) } & $\begin{array}{c}\text { Retune period } \\
\text { (year) }\end{array}$ \\
\hline 2 & 1 & 0.75 & 0.50 & 0.25 & 2 \\
11.39 & 17.74 & 21.20 & 27.03 & 39.82 & 5 \\
13.32 & 20.75 & 24.79 & 31.61 & 46.58 & 10 \\
15.87 & 24.73 & 29.55 & 37.67 & 55.51 & 25 \\
17.80 & 27.74 & 33.14 & 42.26 & 62.26 & 50 \\
19.74 & 30.75 & 36.74 & 46.84 & 69.02 & 100 \\
\hline
\end{tabular}

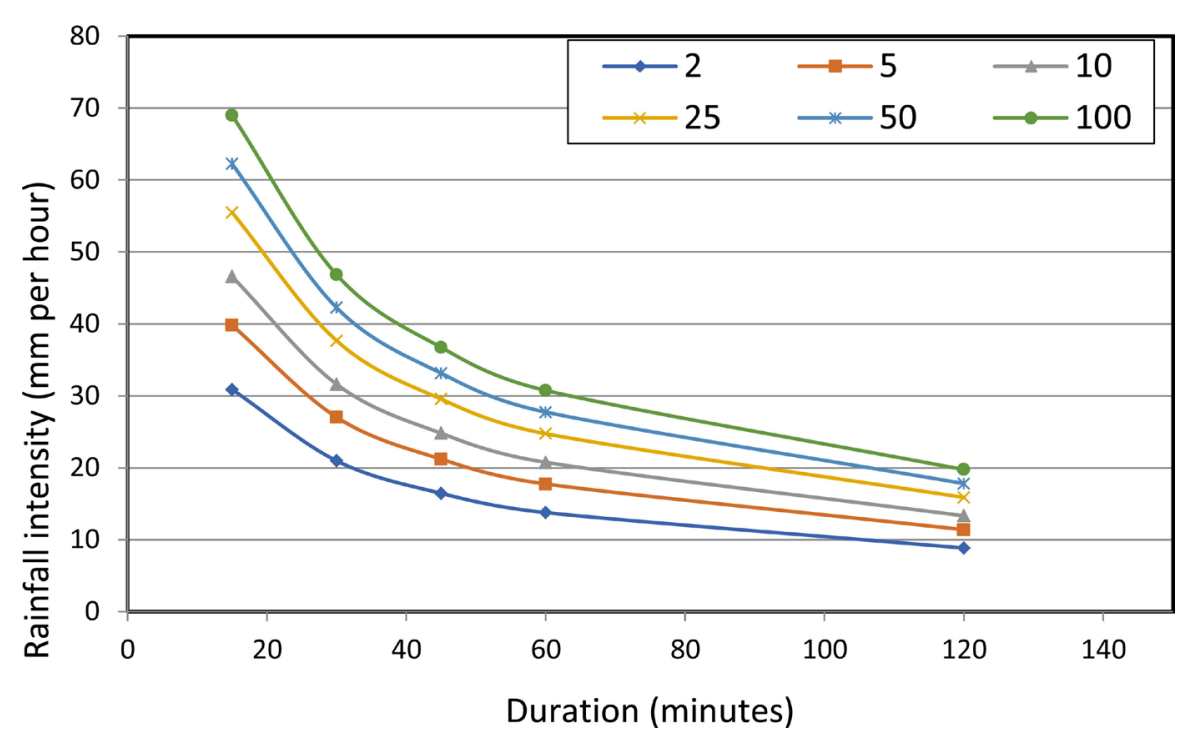

Diagram 1. Bell's method for time-intensity-duration curves of historical rainfalls.

method in this research is that the time of concentration in Bishebone watershed is less than 2 hours. Results showed that for a rainfall with duration of 2 hours and return period of 25 years the intensity would be 15.87 millimeters [33]. 


\subsection{Rainfall-Runoff Simulation}

The results of sensitivity analyze for initial loss and lag time have been shown in Table 5 and Table 6. Results shows that $\mathrm{CN}$ and initial loss have high sensitivity and initial loss is the most important parameter for calibration to be adjusted. As the initial loss changes from -20 to 20 percent, the sensitivity varied from -0.62 to 0.72 .

Table 5. Results of sensitivity analysis of the model to changing initial losses parameters.

\begin{tabular}{ccccc}
\hline $\begin{array}{c}\text { Changing of } \\
\text { parameters (\%) }\end{array}$ & $\begin{array}{c}\text { Values of } \\
\text { parameter }\end{array}$ & $\begin{array}{c}\text { peak } \\
\text { Discharge }\end{array}$ & $\begin{array}{c}\text { Changing of } \\
\text { peak discharge (\%) }\end{array}$ & sensitivity \\
\hline-20 & 17.2 & 10.28 & 14.1 & 0.71 \\
-15 & 18.28 & 17.36 & 11 & 0.55 \\
-10 & 19.35 & 13.21 & 8.2 & 0.41 \\
-5 & 20.43 & 30.43 & 4.5 & 0.23 \\
0 & 21.5 & 18.01 & 0 & 0 \\
5 & 22.58 & 12.05 & -1.6 & -0.08 \\
10 & 23.65 & 9.4 & -5.4 & -0.27 \\
15 & 24.73 & 11.74 & -8.4 & -0.42 \\
20 & 25.8 & 16.71 & -12.4 & -0.62 \\
\hline
\end{tabular}

Table 6. Results of sensitivity analysis of the model to changing lag time parameters.

\begin{tabular}{ccccc}
\hline $\begin{array}{c}\text { Changing of } \\
\text { parameters (\%) }\end{array}$ & $\begin{array}{c}\text { Values of } \\
\text { parameter }\end{array}$ & $\begin{array}{c}\text { Peak } \\
\text { discharge }\end{array}$ & $\begin{array}{c}\text { Changing of } \\
\text { peak discharge (\%) }\end{array}$ & sensitivity \\
\hline-20 & 320 & 10.89 & 8.1 & 0.41 \\
-15 & 340 & 18.01 & 6.1 & 0.31 \\
-10 & 360 & 13.92 & 4.8 & 0.24 \\
-5 & 380 & 31.05 & 1.2 & 0.06 \\
0 & 400 & 18.74 & 0 & 0 \\
5 & 420 & 12.55 & -1.6 & -0.08 \\
10 & 440 & 10.11 & -3.1 & -0.16 \\
15 & 460 & 12.14 & -4.7 & -0.24 \\
20 & 480 & 16.51 & -6.7 & -0.34 \\
\hline
\end{tabular}

Table 7 and Table 8 show the sensitivity of the models to adjustments of parameters for initial loss and lag time respectively.

As it is shown, the curve slop for initial loss is more than the lag time and model has more sensitivity to change in initial loss. In sensitivity analysis, a small change in parameters, causes a significant change in the model. In this case, the model is called sensitive to the parameters. When the curve slope is small, a remarkable change in related parameters has a small effect on response. In this case, the model is called non-sensitive to the parameters. 
Table 7. Evaluated results of predicted and observed different events of Valet and Klardasht stations.

\begin{tabular}{|c|c|c|c|c|c|c|c|}
\hline Level & Date & Observed discharge $\left(\mathrm{m}^{3} / \mathrm{s}\right)$ & Simulated discharge $\left(\mathrm{m}^{3} / \mathrm{s}\right)$ & & Soil Condition P-Value & $\mathrm{R}$ & RMSE \\
\hline Calibration & 5 Oct. 2003 & 11.5 & 11.5 & III & $<0.001$ & 0.97 & 0.44 \\
\hline Calibration & 13 Nov. 2004 & 8.82 & 8.87 & II & $<0.001$ & 0.91 & 0.8 \\
\hline Evaluation & $11 \mathrm{Jul} .2004$ & 16.4 & 16.4 & III & $<0.001$ & 0.97 & 0.64 \\
\hline Calibration & 19 Nov. 2004 & 7.57 & 7.57 & III & $<0.001$ & 0.94 & 0.78 \\
\hline Evaluation & 21 Oct. 2006 & 9.4 & 9.38 & III & $<0.001$ & 0.91 & 1.1 \\
\hline
\end{tabular}

Table 8. The peak discharge and volume of runoff for different Scenarios in the sub-basins of Bishebone (Return period 100 years).

\begin{tabular}{|c|c|c|c|c|c|c|c|c|c|c|c|}
\hline \multirow[b]{2}{*}{$\begin{array}{l}\text { Hydrological } \\
\text { unit }\end{array}$} & \multirow[b]{2}{*}{$\begin{array}{l}\text { Area } \\
\mathrm{Km}^{2}\end{array}$} & \multicolumn{5}{|c|}{ Peak Discharge $\left(\mathrm{m}^{3} / \mathrm{s}\right)$} & \multicolumn{5}{|c|}{ Runoff Volume } \\
\hline & & $\begin{array}{c}\text { Before } \\
\text { performing }\end{array}$ & $\begin{array}{c}\text { After } \\
\text { biological } \\
\text { performing }\end{array}$ & $\begin{array}{c}\text { After } \\
\text { mechanical } \\
\text { performing }\end{array}$ & $\begin{array}{c}\text { After } \\
\text { biological } \\
\text { and } \\
\text { Mechanical } \\
\text { performing }\end{array}$ & $\begin{array}{c}\text { After } \\
\text { complete } \\
\text { performing } \\
\text { of } \\
\text { watershed } \\
\text { plan }\end{array}$ & $\begin{array}{c}\text { Before } \\
\text { performing }\end{array}$ & $\begin{array}{c}\text { After } \\
\text { biological } \\
\text { performing }\end{array}$ & $\begin{array}{c}\text { After } \\
\text { mechanical } \\
\text { performing }\end{array}$ & $\begin{array}{c}\text { After } \\
\text { biological } \\
\text { and } \\
\text { Mechanical } \\
\text { performing }\end{array}$ & $\begin{array}{c}\text { After } \\
\text { complete } \\
\text { performing } \\
\text { of } \\
\text { watershed } \\
\text { plan }\end{array}$ \\
\hline I & 16.23 & 5.59 & 6.22 & 5.59 & 6.22 & 5.60 & 27.10 & 30.18 & 27.10 & 30.18 & 27.10 \\
\hline II & 4.48 & 1.92 & 2.39 & 1.92 & 2.39 & 1.92 & 9.32 & 11.56 & 9.32 & 11.56 & 9.32 \\
\hline III & 2.28 & 0.22 & 0.31 & 0.22 & 0.31 & 0.22 & 1.07 & 1.48 & 1.07 & 1.48 & 1.07 \\
\hline IIX & 12.69 & 6.29 & 6.45 & 6.29 & 6.45 & 6.29 & 30.45 & 31.22 & 30.45 & 31.22 & 30.45 \\
\hline IV & 3.08 & 1.01 & 0.75 & 1.01 & 0.75 & 1.01 & 4.87 & 3.63 & 4.87 & 3.63 & 4.87 \\
\hline IX & 8.65 & 4.33 & 4.37 & 4.33 & 4.36 & 4.34 & 21.01 & 21.19 & 21.01 & 21.10 & 21.01 \\
\hline $\mathrm{V}$ & 7.17 & 1.83 & 1.20 & 1.83 & 1.20 & 1.83 & 8.89 & 5.81 & 8.89 & 5.81 & 8.89 \\
\hline VI & 8.71 & 6.01 & 6.47 & 6.01 & 6.48 & 6.02 & 29.10 & 31.37 & 29.10 & 31.37 & 29.19 \\
\hline VII & 7.12 & 5.68 & 6.15 & 5.68 & 6.15 & 5.68 & 27.56 & 29.83 & 27.56 & 29.83 & 27.56 \\
\hline $\mathrm{X}$ & 9.12 & 4.58 & 5.22 & 4.58 & 5.22 & 4.77 & 22.15 & 25.25 & 22.15 & 25.25 & 23.16 \\
\hline SUM & 79.53 & 20.63 & 22.25 & 19.19 & 20.54 & 18.58 & 181.32 & 191.66 & 181.32 & 191.66 & 182.91 \\
\hline
\end{tabular}

In calibration operations the value of peak discharge is used as the calibration index due to the importance of peak discharge in flood event. Table 7 shows the results of the calibration and validation for Gelvard station. RMSE index, correlation coefficient and Student's t-test was utilized for evaluation statistic result of model [34] [35].

As it is shown in Table 5, there is a good correlation between simulated values and observed values for 3 flood events in calibration step $(r>0.9$; $P<0.001)$. Using compare means test and Student's t-test, there was no significant difference between observed and simulated values as a result we can trust the model for simulate the peak discharge. Same results were observed for validation step $(\mathrm{r}>0.9 ; \mathrm{P}<0.001)$. Small values for RMSE in calibration and validation step show the applicability of the model for prediction of peak discharge in Bishebone watershed. 


\subsection{Flow Simulation by Using HEC-HMS Model to Evaluate the Mechanical Operation}

The result of Table 8 shows that for a 100 year return period after watershed operations the discharge was estimated about $19.19 \mathrm{~m}^{3} / \mathrm{s}$ that shows the decline up to 6.95 percent of peak discharge.

\subsection{Flow Simulation Using HEC-HMS Model to Evaluate the Biological Operation}

According to the land use map, all the sub-basins except V and VI have been altered from forest land to agricultural land and have impact on curved number and initial loss due to expansion of agricultural area. Only in two sub-basin V and VI have experienced the increase in biological treatment and the impact is obvious on curve number.

According to Table 8, the peak discharge with 100 year return period in sub-basin IV has been reduced from 1.83 to $1.2 \mathrm{~m}^{3} / \mathrm{s}$ that equals to 34 percent decline. The same behavior was observed for sub-basin V. For the rest of the sub-basins we observed the increase in $\mathrm{CN}$ and as a result, the increase in peak discharge and volume of surface runoff.

\subsection{Flow Simulation Using HEC-HMS in Order to Evaluate the Combination of Mechanical and Biological Treatments}

Results showed that the pick discharge in this scenario for a 100 year slightly decreased from 20.63 to $20.54 \mathrm{~m}^{3} / \mathrm{s}$ (Table 9).

\subsection{Flow Simulation Using HEC-HMS in Order to Evaluate the Watershed Operations in Case of Complete Mechanical Operations}

In this step, according to optimized parameters from first level, amount of changing peak discharges were calculated in case of complete operations of mechanical treatments. Results showed that discharge with return period of 2, 5, 10, $25,50,100$ year will have respectively $2.71,2.5,2.51,5.37,8.23,9.94$ percent decrease in case of complete mechanical treatments of the watershed (Table 9).

Table 9. Difference of peak discharge in Bishebone basin.

\begin{tabular}{cccccccccc}
\hline $\begin{array}{l}\text { Return } \\
\text { period performing }\end{array}$ & $\begin{array}{c}\text { After } \\
\text { biological } \\
\text { performing }\end{array}$ & $\begin{array}{c}\text { Difference into } \\
\text { before } \\
\text { performing } \\
(\%)\end{array}$ & $\begin{array}{c}\text { After } \\
\text { mechanical } \\
\text { performing }\end{array}$ & $\begin{array}{c}\text { Difference into } \\
\text { before } \\
\text { performing } \\
(\%)\end{array}$ & $\begin{array}{c}\text { After } \\
\text { biological and } \\
\text { Mechanical } \\
\text { performing }\end{array}$ & $\begin{array}{c}\text { Difference into } \\
\text { before } \\
\text { performing } \\
(\%)\end{array}$ & $\begin{array}{c}\text { After complete } \\
\text { performing of } \\
\text { watershed plan }\end{array}$ & $\begin{array}{c}\text { Difference into } \\
\text { before } \\
\text { performing } \\
(\%)\end{array}$ \\
\hline 2 & 0.04 & 0.08 & 88.76 & 0.04 & -2.94 & 0.08 & 82.24 & 0.04 & -2.71 \\
5 & 0.98 & 1.25 & 27.12 & 0.96 & -1.99 & 1.23 & 25.69 & 0.96 & -2.50 \\
10 & 3.13 & 3.57 & 14.10 & 3.11 & -0.62 & 3.56 & 13.92 & 3.05 & -2.51 \\
25 & 8.19 & 9.19 & 12.21 & 7.96 & -2.72 & 8.61 & 5.14 & 7.75 & -5.37 \\
50 & 13.78 & 15.09 & 9.50 & 13.04 & -5.37 & 13.89 & 0.79 & 12.65 & -8.23 \\
100 & 20.63 & 22.25 & 7.85 & 19.19 & -6.95 & 20.54 & -0.41 & 18.58 & -9.94 \\
\hline
\end{tabular}




\section{Discussions and Conclusions}

Many SWC techniques have been performed on watersheds in different hydro-climatic regions without evaluating the impact of the location and number of the structures that is needed for the watershed treatments. Watershed management projects should consider all socio-economic aspects of SWC techniques. Present study offers a cost-effective approach for estimating the applicability of mechanical and biological watershed treatments on surface runoff and mitigating the impact of flood events. Using the results of this study and comparing the volume of runoff and peak discharge we would be able to determine the volume of watershed management operations before starting the projects. Also the results show the effectiveness of biological treatments which is relatively economical.

In this study 4 different scenarios for assessing the impact of watershed operations on surface runoff were performed by using a rainfall-runoff model (HEC-HMS) in Bishebone watershed (Table 9). The studied scenarios consist of biological treatments, mechanical treatments, combination effect of biological and mechanical treatments and complete performing of watershed plans. In biological operations, result shows that discharge of flood with return periods of 2 , $5,10,25,50,100$ year shows respectively $88.76,27.12,14.1,12.21,9.5,7.85$ percent increasing in all basins and shows that impact of biological treatments in long return periods is relatively less than that of shorter return periods. Only in two sub-basins of the Bishebone watershed (IV and V) an increase in the biological treatments was observed. According to Table 9, the amount of peak discharge for return period of 100 year has been reduced from 1.83 to $1.2 \mathrm{~m}^{3} / \mathrm{s}$ which equals to 34 percent. The same behavior was observed for the sub-basin $\mathrm{V}$.

The results for mechanical operations show that, the discharge for 100 year return period, after performing watershed operations, was estimated about 19.9 $\mathrm{m}^{3} / \mathrm{s}$ that shows 6.95 percent decline in peak discharge. Decline in peak discharge also occurred in conjunction zone between V and VI (J134) sub-basins. The peak discharge or the sub-basin VI this amount was $6.14 \mathrm{~m}^{3} / \mathrm{s}$.

The results for the combination of mechanical and biological scenario show that, in a return period of 100 year, the peak discharge in watershed outlet has been reduced from 20.63 to $20.54 \mathrm{~m}^{3} / \mathrm{s}$. The insignificant impact is the result of increase in $\mathrm{CN}$ values of some sub-basins.

The results for the complete mechanical treatments scenario show that, for the discharge with return periods of 2, 5, 10, 25, 50 and 100 years, there will be decline in peak discharge which equals to $2.71,2.5,2.51,5.37$ and 8.23 percent respectively. The peak discharge for a 100 years return period will decrease from 20.63 to $18.58 \mathrm{~m}^{3} / \mathrm{s}$. The peak discharge for a 100 years return period will decrease from 20.63 to $18.58 \mathrm{~m}^{3} / \mathrm{s}$. According to this study, the impact of check dams on floods with higher return periods is relatively more than that of shorter return periods.

\section{Conflicts of Interest}

The authors declare no conflicts of interest regarding the publication of this paper. 


\section{References}

[1] Moosiv, A.A. and Mirzaie, A. (2006) Report: Introduction of Flood Database. Ministry of Jihad-E-Agriculture.

[2] Heshmatpour, A. (2001) Performance Investigation of Watershed Management in Flood Control of Ghaz Mahale Watershed Management Design (Case Study: Golestan Province). Journal of Agricultural Sciences and Natural Resources, 13, 32-44.

[3] Karbowski, A. (1993) Optimal Flood Control in Multireservoir Cascade Systems with Deterministic Inflow Forecasts. Water Resources Management, 7, 207-223. https://doi.org/10.1007/BF01675304

[4] Doty, R.D. (1971) Contour Trenching Effects on Stream Flow from a Utah Watershed. USDA Forest Service Research Paper INT, 98. Intermountain Forest \& Range Experiment Station, Ogden, Utah.

[5] Noble, E.L. (1963) Sediment Reduction through Watershed Rehabilition. USDA Forest Service, Intermountain Region, Ogden, UT, 29 p.

[6] Satterland, J.B. (1962) Soil Conservation Service-Engineering Field Manual for Conservation Practices.

[7] Marsh, W.M. (2005) Landscape Planning: Environmental Applications (No. Sirsi) (i9780471485834).

[8] Vaezi, A.R., Abbasi, M., Keesstra, S. and Cerdà, A. (2017) Assessment of Soil Particle Erodibility and Sediment Trapping Using Check Dams in Small Semi-Arid Catchments. Catena, 157, 227-240. https://doi.org/10.1016/j.catena.2017.05.021

[9] Guyassa, E., Frankl, A., Zenebe, A., Poesen, J. and Nyssen, J. (2017) Effects of Check Dams on Runoff Characteristics along Gully Reaches, the Case of Northern Ethiopia. Journal of Hydrology, 545, 299-309. https://doi.org/10.1016/j.jhydrol.2016.12.019

[10] Castillo, V.M., Mosch, W.M., García, C.C., Barberá, G.G., Cano, J.N. and López-Bermúdez, F. (2007) Effectiveness and Geomorphological Impacts of Check Dams for Soil Erosion Control in a Semiarid Mediterranean Catchment: El Cárcavo (Murcia, Spain). Catena, 70, 416-427. https://doi.org/10.1016/j.catena.2006.11.009

[11] Brooks, A.P., Brierley, G.J. and Millar, R.G. (2003) The Long-Term Control of Vegetation and Woody Debris on Channel and Flood-Plain Evolution: Insights from a Paired Catchment Study in Southeastern Australia. Geomorphology, 51, 7-29. https://doi.org/10.1016/S0169-555X(02)00323-9

[12] Simonovic, P. (2002) Two Non-Structural Measures for Sustainable Management of Floods. Proceeding of the International Workshop on London, Ontario, Canada, 65-81.

[13] Scharffenberg, W.A. and Fleming, M.J. (2006) Hydrologic Modeling System HEC-HMS: User's Manual. US Army Corps of Engineers, Hydrologic Engineering Center.

[14] Chu, X. and Steinman, A. (2009) Event and Continuous Hydrologic Modeling with HEC-HMS. Journal of Irrigation and Drainage Engineering, 135, 119-124. https://doi.org/10.1061/(ASCE)0733-9437(2009)135:1(119)

[15] Anderson, M.L., Chen, Z.Q., Kavvas, M.L. and Feldman, A. (2002) Coupling HEC-HMS with Atmospheric Models for Prediction of Watershed Runoff. Journal of Hydrologic Engineering, 7, 312-318. https://doi.org/10.1061/(ASCE)1084-0699(2002)7:4(312)

[16] Sahour, H., Mokhtari, A. and Ghahfarokhi, S.S. (2016) Rainfall-Runoff Modeling 
Using Remotely Sensed Data and Hydrologic Modeling System. Ecology, Environment and Conservation Paper, 22, 1725-1745.

[17] Saghafian, B., Farazjoo, H., Bozorgy, B. and Yazdandoost, F. (2008) Flood Intensification Due to Changes in Land Use. Water Resources Management, 22, 1051-1067. https://doi.org/10.1007/s11269-007-9210-Z

[18] Solaimani, K., Mohammadi, H., Ahmadi, M.Z. and Habibnejad, M. (2005) Flood Occurrence Hazard Forecasting Based on Geographical Information System. International Journal of Environmental Science \& Technology, 2, 253-258. https://doi.org/10.1007/BF03325884

[19] Sahour, H., Mokhtari, A. and Tehrani, E.N. (2014) Effects of Land Use/Land Cover Changes on Surface Runoff (A Case Study in Siahroud Watershed, Iran). Elixir Remote Sensing, 74, 26867-26870.

[20] Ardalan, H., Eslami, H. and Nariman-Zadeh, N. (2009) Piles Shaft Capacity from CPT and CPTu Data by Polynominal Neural Networks and Genetic Algorithms. Journal of Computers and Geotechnics, 36, 616-625. https://doi.org/10.1016/j.compgeo.2008.09.003

[21] Tarzban, S. and Hadian, A.A. (2008) Tehran: Ministry of Education. 9th Edition, MF. Geography of Mazandaran Province, 3-7. (In Persian)

[22] Nikzad, T.E., Sahour, H. and Booij, M.J. (2018) Trend Analysis of Hydro-Climatic Variables in the North of Iran. Theoretical and Applied Climatology, 1-13.

[23] Mohammadian, M., Arfania, R. and Sahour, H. (2017) Evaluation of SEBS Algorithm for Estimation of Daily Evapotranspiration Using Landsat-8 Dataset in a Semi-Arid Region of Central Iran. Open Journal of Geology, 7, 335-347. https://doi.org/10.4236/ojg.2017.73023

[24] Jiang, R. (2001) Investigation of Runoff Curve Number Initial Abstraction Ratio. MS Thesis, Watershed Management, University of Arizona, Tucson, 120 p.

[25] Misha, S.K. and Singh, V.P. (2003) Soil Conservation Service Curve Number (SCS-CN) Methodology. Kluwer Academic Publishers, Dordrecht. https://doi.org/10.1007/978-94-017-0147-1

[26] Misha, S.K. and Singh, V.P. (2004) Long-Term Hydrological Simulation Based on the Soil Conservation Service Curve Number. Hydrological Processes, 18, 1291-1313. https://doi.org/10.1002/hyp.1344

[27] Jakeman, A.J., Ghassemi, F. and Dietrich, C.R. (1990) Calibration and Reliability of an Aquifer System Model Using Generalized Sensitivity Analysis. Proceedings of the Conference, Hague, September 1990, No. 195.

[28] Razavi, S., Tolson, B.A. and Burn, D.H. (2012) Review of Surrogate Modeling in Water Resources. Water Resource Research, 48.

[29] Obot, N.I., Chendo, M.A.C., Udo, S.O. and Ewona, I.O. (2010) Evaluation of Raifall Trends in Nigeria for 30 Years (1978-2007). International Journal of Physical Sciences, 5, 2217-2222.

[30] Rasel, H.M., Imteaz, M.A. and Mekanik, F. (2017) Multiple Regression Modelling Approach for Rainfall Prediction Using Large-Scale Climate Indices as Potential Predictors. International Journal of Water, 11, 209-225. https://doi.org/10.1504/IJW.2017.085879

[31] Costache, R. (2014) Using GIS Techniques for Assessing Lag Time and Concentration Time in Small River Basins. Case Study: Pecineaga River Basin, Romania. Geographia Technica, 1, 31-38.

[32] Gericke, O.J. and Smithers, J.C. (2014) Review of Methods Used to Estimate Cat- 
chment Response Time for the Purpose of Peak Discharge Estimation. Hydrological Sciences Journal, 59, 1935-1971. https://doi.org/10.1080/02626667.2013.866712

[33] Bell, F.C. (1969) Generalized Rainfall-Duration-Frequency Relationship. Journal of the Hydraulics Division, 95, 311-327.

[34] Li, Z. and Yu, Z. (2008) Rainfall-Runoff Simulation and Flood Forecasting for Huaihe Basin. Water Science and Engineering, 1, 24-35.

[35] Bao, H. and Zhang, G. (2010) Hydrological Daily Rainfall-Runoff Simulation with BTOPMC Model and Comparison with Xin'anjiang Model. Water Science and Engineering, 3, 121-131. 